\title{
1/2500地形図標準データファイルを用いた 高度な地物データ GISの自動構築に関する研究 DEVELOPMENT OF AN AUTOMATED CONSTRUCTION ALGORITHM OF ADVANCED DELINEATION GIS DATA USING 1:2500 TOPOLOGICAL MAP
}

\author{
田内 裕人 ${ }^{1} \cdot$ 天口 英雄 ${ }^{2} \cdot$ 河村 $^{\text {明 }^{3}} \cdot$ 中川 直子 ${ }^{4}$ \\ Hiroto TANOUCHI, Hideo AMAGUCHI, \\ Akira KAWAMURA and Naoko NAKAGAWA

\begin{abstract}
1 学生会員 修（環境） 首都大学東京 都市環境科学研究科（† 192-0397 東京都八王子市南大沢 1-1）
2 正会員 博（工） 首都大学東京助教 都市環境科学研究科（† 192-0397 東京都八王子市南大沢 1-1）

3 正会員 工博 首都大学東京教授 都市環境科学研究科（T 192-0397 東京都八王子市南大沢 1-1）
\end{abstract} \\ 4 正会員 博（理） 首都大学東京特任准教授 都市環境科学研究科（ $\mathbf{T}$ 192-0397 東京都八王子市南大沢 1-1）
}

\begin{abstract}
In recent years, the use of advanced delineation GIS data (ADGD) has become invaluable in studies that require accurate spatial distribution of land use. However, the preparation of ADGD, especially for urban catchment areas, is often tedious, time consuming and prone to errors, since these are mostly constructed manually using a digitized map. In this study, a computer algorithm (automated construction algorithm) was developed to automatically construct ADGD from a digitized 1:2500 topological map, using only geographical point features and geographic object boundaries that have land use attributes. A portion of the digitized map of the Kanda River basin was used to examine the accuracy of the newly developed algorithm. Evidences show that this algorithm can generate similar to more accurate geographical features when compared with the manual approach. The automated construction algorithm, thus, provide an accurate and efficient alternative in constructing ADGD, which can benefit future GIS-related studies.
\end{abstract}

Key Words: Advanced delineation GIS data, Digital mapping datafile, Land use classification, Urban hydrology, GIS automated construction

\section{1. はじめに}

都市流域では，建物や道路などの不浸透域と公園や グラウンドなどの浸透域が複雑に分布している。この ような都市流域の水循環過程を解明するには，対象と する流域の浸透特性，すなわち浸透域・不浸透域の分布 状況を正確に表現した土地利用データを作成し，これ を入力データとして利用できる分布型水循環モデルを 構築することが必要となる。これまでに提案されてい る分布型水循環モデルでは, 入力可能なデータの制約 上の理由やモデル構築の容易さから, グリッド型のモ デルが多用されている 1) 4). 特に都市流域で多用され る細密数值情報では最小単位である $10 \mathrm{~m}$ のグリッド内 においても複数の土地利用が混在しているのが実態で あり, 都市流域の正確な浸透面積率が反映されず, 解析 結果に大きな影響を与える可能性が示唆 5) されている. 以上の背景の下, 著者らはグリッド型の土地利用区分 と比較し流域の土地利用を正確に表現可能なポリゴン 型の GIS（Geographic Information System ; 地理情報シ ステム) データを用いて, 道路, 河道, 建物, 駐車場, 畑などの細かな土地利用種別を表現することが可能な
高度な地物データ GIS を考案し，これらを用いた都市 洪水流出解析モデル 6) 8), および都市地下水涵養モデ ル9),10) の開発を行っている. なお, 海外における都市 流域の流出解析に用いられているベクトル型 GIS デー タは著者らの地物データ GIS と比べて土地利用区分が 粗いものとなっている. 例えば, Sample ら 11) は商業 地，低層住宅地および中層住宅地など都市計画上の用 途区分を用い, Rodriguez ら 12) は地籍境界, 建物, 道 路などを用いている程度である。

さらに著者らは高度な地物データ GIS を活用し，神

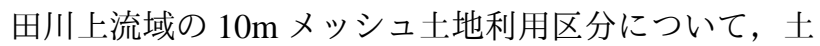
地利用区分ごとの正確な浸透面積率の推定を試みてい る ${ }^{5)}$.このように高度な地物データ GIS として作成さ れたデータは都市流域の水循環を解明するうえで必要 不可欠な土地利用データであるといえる.

しかし現在一般に入手可能なべクトル型の GIS デー タには，直接流出量等の算定に必要な浸透・不浸透を考 慮した土地利用種別の情報が含まれていない.このた め高度な地物データ GIS の構築には, 1/2500 地形図や 航空写真を基に個々の土地利用種別の判別を行い, 手 作業により各地物の浸透特性を一つ一つ設定しなけれ 
ばならず，この作業には膨大な時間と労力が必要とな る. 高度な地物データ GIS の構築を自動化することに より正確な土地利用情報の入手が容易になれば, 都市 域の高精度水循環モデル普及の一助となることが期待 される.

著者らはこれまで, 既存の GIS データを用いて高度 な地物データ GIS が構築可能かどうかを検討 ${ }^{13)} し て ~$ きた.まず，最も基礎的な GIS データである衛星画像 や航空写真について検討した。画像データから建物な どの地物を抽出する手法が数多く開発されている ${ }^{14), 15)}$ ものの, 衛星写真については植生や建物の陰に隠れた 地物の境界線を正確に抽出することは非常に困難であ り, また航空写真から地物の抽出を行う場合には, 地 物の境界線を正確に抽出することが困難であるという 問題があった. 次いで, ベクトルデータである数值地図 2500 16) の検討を行った。本データはさまざまな分野で 利用が進んでおり, GIS システムを構築する際の最も 基本的なデータが収められている．本データの街区界 を用いることにより詳細な道路要素を作成することは 可能であるが, 街区内土地利用についての情報は公共 建物のみで, その他の建物, 緑地および畑などの細か な土地利用種別に関する情報は無く, 高度な地物デー タ GIS の自動構築には不適切であると判断した。次い で, 近年各自治体で配備が進みつつある 1/2500 地形図 標準データファイル（以下これを「地形図データ」と 呼ぶ）17）を用いることを検討した。本データは国土交 通省公共測量作業規定にて規定された Digital Mapping フォーマット17) に準拠し作成された電子地形図データ であり, 高度な地物データ GIS の構築に必要となる街 区, 道路および河道の境界データに加え, 街区内土地利 用情報として公園, 駐車場, 畑および芝地などの土地 利用情報が収められている。本データは, 都市流域の 雨水流出機構に影響を与える土地利用構造が詳細に記 述された貴重なデータであると考えられるが，本デー タから雨水流出解析を目的として土地利用情報を抽出・ 活用した事例は著者らの知る限り見当たらない.

そこで, 本研究では地形図データを用いて高度な地 物データ GIS の構築を自動化する手法を開発・検討す る。また同手法を用い神田川上流域の高度な地物デー タ GIS を構築し, 既存の手作業で構築した高度な地物 データ GIS および航空写真との比較を行い本手法の評 価を行う。

\section{2. 高度な地物データ GIS の自動構築}

表-1 は，地形図データのデータタイプ，レイヤ名お よび高度な地物データ GIS での利用目的を示す. 図-1 は地形図データから高度な地物データ GIS の構築手順 を示したもので，その流れは，a）地形図データを GIS 用ファイル (シェープファイル) に変換 ${ }^{18)}$, b ) 基礎的 地物データ GIS の準備, c) 街区内土地利用要素の構築, d）道路・河道要素の分割である. 本研究では, 高度な地
表-1 地形図データの内容とその用途

\begin{tabular}{ccc}
\hline \hline データタイプ & レイヤ名 & おもな用途 \\
\hline 道路境界線 & 道路・街区要素の分離 \\
線路 & 鉄道の抽出 \\
ポリライン & 建物の抽出 \\
& プール外線 & プールの抽出 \\
& 水涯線 & 河道要素・池の抽出 \\
& 柵, 塀 & 街区要素の分割 \\
& 区域界, 植生界 & 街区要素の分割 \\
\hline 公園 & 公園の抽出 \\
駐車場 & 駐車場の抽出 \\
テニインコート & テニスコートの抽出 \\
ポイ & グラウンドラウンドの抽出 \\
(地図記号) & 畑, 果樹園 & 畑の抽出 \\
& 芝地, 庭園 & 芝地の抽出 \\
& 広葉樹林, 針葉樹林等 & 緑地の抽出 \\
& 砂礫地, 荒地 & 裸地の抽出 \\
\hline \hline
\end{tabular}

物データ GIS の構築において, これまで多大な時間と 労力が必要であった c）およびd）に対するデータ処理 の自動化を行う。ここで, GIS データの処理には ESRI 社の ArcGIS ${ }^{19)}$ を使用し, 自動化プログラムは ArcGIS のマクロとしてプログラミング言語である Visual Basic for Applications（VBA）を用い記述した. GIS データ フォーマットとしては shape ファイルを用いている.

\section{（1）基礎的地物データ GIS の準備}

基礎的地物データ GIS は, 高度な地物データ GIS を 自動構築するための入力データとして用いられる河道, 池, 街区, 建物および道路の 5 つの土地利用種別によ り構成される。ここでは表-1のポリライン型である水 涯線, 道路境界線および建物外周線を用いることによ り, ポリゴン型の河道 (池) 要素, 街区要素および建 物要素をそれぞれ作成する。

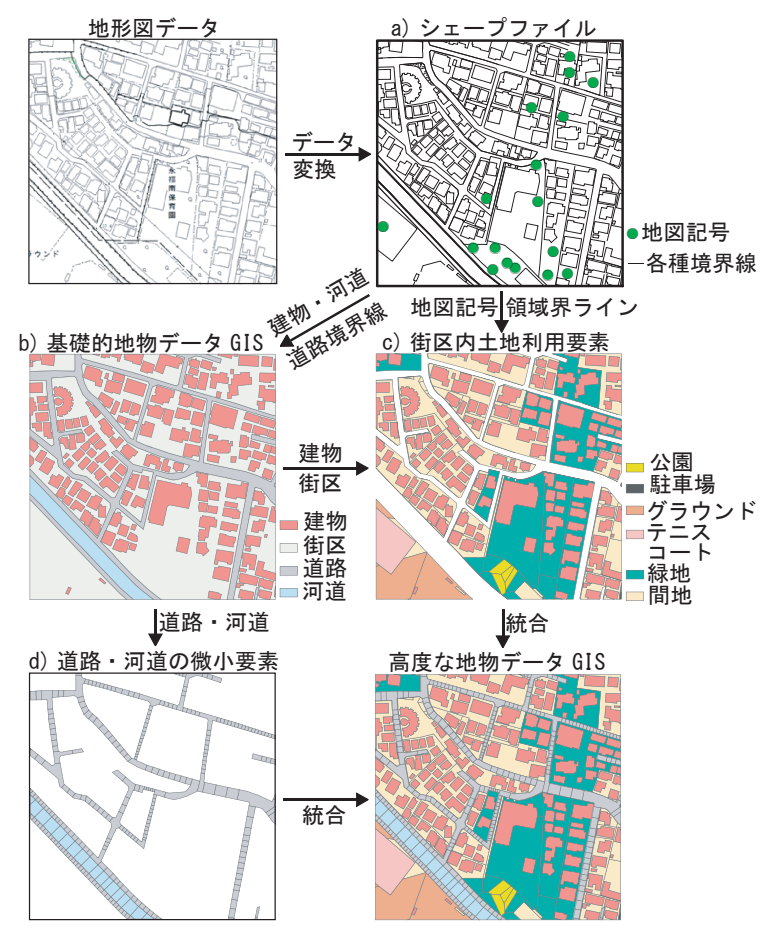

図-1 高度な地物データ GIS の構築手順 


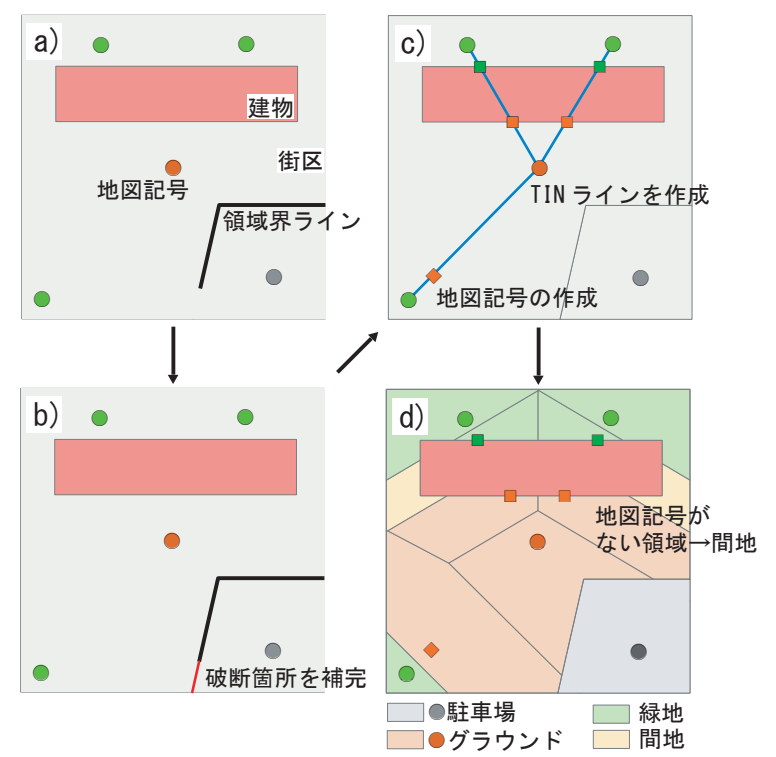

図-2 街区内土地利用要素の構築手順

ポリライン型の境界線をポリゴン型の要素に変換す るには，境界線が閉じていることが前提である．地形 図データの水涯線および道路境界線は地形図上でその 境界を示すのみで不連続となっており，そままではポ リゴン型に変換することはできない，そこで，境界線 の特性に応じて次のような処理を行うこととする.

水涯線は河道や池などの水際を視覚的に表現したも ので，これと道路境界線が重なる場合には水涯線が明 示されていない.このような水涯線の不連続個所は少 いため, 手作業で新たな境界線の追加を行うものとす る. なお, 後述する神田川上流域においては 30 分程度 で線の補完を完了した。こうして修正した水涯線を用 いて河道要素の作成を行う.

また道路については, 地形図データでは袋小路など において道路境界線が存在しないため閉じた街区を構 築できない.すなわちポリラインの始点と終点が一致 せずポリゴンが作成できない，そのため始点と終点が 一致しない不連続箇所を抽出し，そこを直線で結びポ リゴン（街区要素）とする.

建物外周線には不連続箇所は存在しないため，その ままポリゴン化を行い建物要素とする. なお, 道路要 素は構築した河道・池・建物・街区要素を対象領域から 除くことで簡単に抽出可能である.

\section{(2) 街区内土地利用要素の構築}

\section{a) 手順の概要}

図-2 は, 街区内の土地利用要素を構築していく手順 の概要を示したものである. まず，表-1に示すポリラ イン型の柵, 区域界および植生界（以下これを総称し 「領域界ライン」と呼ぶ）が要素内に存在する場合は, そのラインを用い街区要素を分割する. 次いで, 要素 内に含まれる公園, 駐車場, テニスコート, その他植生 状況などの土地利用状況を表すポイント型の地図記号 を母点とするティーセン分割を行うとともに，その土 地利用情報を割り当てる.

\section{b) 領域界ラインによる街区要素の分割}

まず，街区要素と領域界ラインを重㸚合わせ（図-2 a））, 街区内に領域界ラインが存在し, かつそれが不 連続となっている場合, 領域界ラインを延長して連続 化を行う（図-2 b））。次いで, 連続化した領域界ライ ンを用い街区要素を分割し, 各要素内に含まれる地図 記号を用い土地利用種別の設定を行う。ここで, 要素 内に含まれる地図記号が 1 つの場合には, その地図記 号により土地利用種別を設定するが, 地図記号が複数 の場合には以下の手順により要素をさらに分割する.

c) 地図記号による街区要素の分割と属性設定

複数の地図記号を含む領域に対し, 地図記号の影響 範囲を設定する手法として，ティーセン法を用いるこ とが考えられる.しかしながら, 街区内には建物が存在 しており, 建物は街区内の土地利用の明確な境界とな るため, これを優先した領域の分割および属性の付加 を行う必要がある. また, 土地利用の情報をもつ地図記 号はグラウンドなどのように街区の土地利用を代表す るものと, 広葉樹林などの植生を示すものとが混在し ている．たとえばグラウンド内の樹林などはライン状 に立地することが多く，こうした場合植生を示す地図 記号もライン状に複数与えられている.これにティー セン法を適用すると, 地図記号の少ないグラウンドな どの面積が過小評価されてしまう。そこで, 以上の問 題を解決するために, 街区要素内に複数の地図記号が 存在する場合の要素の分割は, 地図記号が持つ特性を 考慮した新たな補助データを作成することにより行う こととする.なお，ここでは図-2に従い緑地以外の土 地利用種別としてグラウンドを取り上げる.

まず図-2 c）に示すように，地図記号を頂点とするポ リライン型の不整三角形網（以下 TIN ライン）を発 生させる. 建物要素の境界と TIN ラインが交差する箇 所にポイントを発生させ，これに対し近傍の地図記号 と同じ土地利用属性として, 建物要素の上側には緑地 を，下側にはグラウンドを設定する（図-2c）の口印）.

ライン状に植樹されているグランウドや校庭などの 隅にある樹木群に対して, 以下の処理を行う. 航空写 真などの目視から緑地の地図記号の影響半径は概ね $5 \mathrm{~m}$ 程度と判断し, TIN ライン上には緑地の地図記号から 影響半径の 2 倍である $10 \mathrm{~m}$ の位置にグラウンドの属性 值を持つポイントを発生させる，なお，TIN ラインが $20 \mathrm{~m}$ よりも短い場合は TIN ラインの中点にポイントを 発生させる（図-2c）のっ印）。

最後に, 地図記号およびTIN ライン上に発生させた 新たなポイントを用いてティーセン法により街区要素 を分割するとともに，土地利用属性の設定を行う（図-2 d））. なお, 地図記号が存在しない要素は間地と設定 する.

\section{(3) 道路および河道の微小要素作成}

道路・河道は, 著者らが開発した洪水流出解析モデ ル ${ }^{8)}$ では水路と見なして計算するので, 道路・河道の 


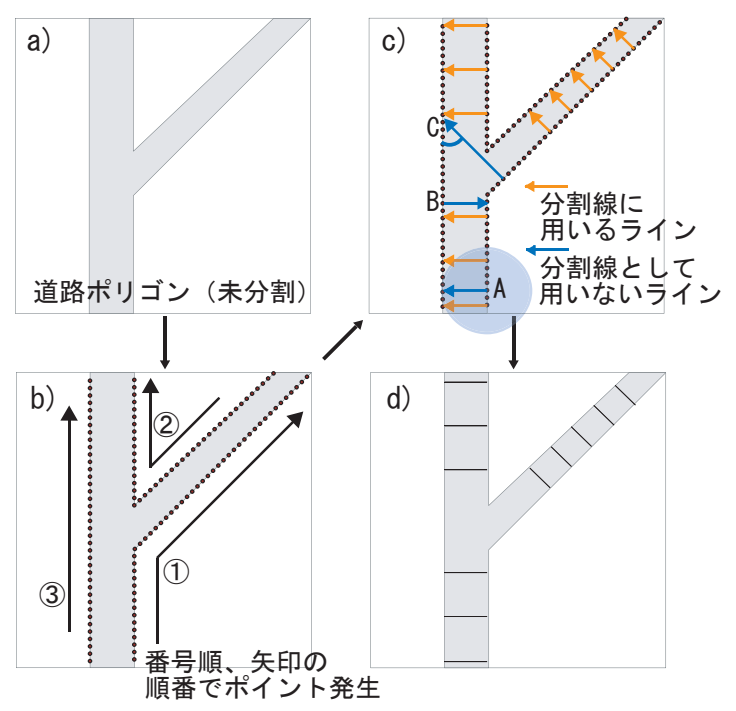

図-3 道路・河道の微小要素の構築

微小要素はその幅と同程度の間隔で流路に直交して分 割・構築されることが望ましい。このような条件を満た すよう, 図-3に示す手順で道路・河道要素を分割する. まず，道路・河道要素（図-3 a））に対し, 要素の外 周線上に, 時計回りに $1 \mathrm{~m}$ おきに始点から終点までポ イントを発生させ, 外周線内での発生順序番号と外周 線の要素番号を属性として設定する（図-3b））。なお， $1 \mathrm{~m}$ おきにポイントを発生させるのは, 道路の最小幅員 が $3 \mathrm{~m}$ 程度であり $1 \mathrm{~m}$ 単位で道路要素の分割を検討すれ ば目的の長さでの分割が十分可能となるためである.

次いで, 発生させたポイントを始点とし, ポリゴン の内側に向かって鉛直に伸ばした線がポリゴンの外周 線と交差するポイントを終点として, 以下の条件を満 たす場合にはその長さを道路の要素幅として記録する とともに分割線として保存する（図-3 c））。

A 始点ポイントを中心とする道路要素幅を半径の円 に，既に作成した要素分割線が存在しないこと

B 始点の要素番号が終点のそれより大きい，または 始点と終点の要素番号が同じ場合, 始点の発生順 序番号が終点付近にあるポイントの発生順序番号 よりも小さいこと

$\mathrm{C}$ 道路境界線が完全に平行ではないため, 終点にお ける分割線と外周線のなす角度が $90 \pm 15$ 度の範囲 に入ること

なお，図-3c）に A，B，Cの条件を満たさない場合に ついて青矢印で示す。条件 A では正方形に近い単純な 形状の微小要素の作成が, 条件 B では道路の片側から のみ分割線を発生させる処理および道路要素における 袋小路部分の処理が, また条件 C では道路要素の延長 方向に対して概ね直行方向への分割がそれぞれ可能と なる.さらに幅の広い片側 2 車線以上の道路では中央 分離帯が設けられていることが多く車線ごとに異なる 要素とするほうが妥当と考えられるので, 道路分割線 の中心点を結ぶことで道路中心線を発生させ，それに より分割する. 最後に建物要素, 街区内土地利用要素

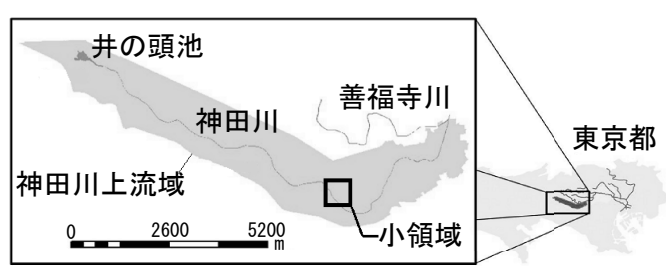

図-4 神田川上流域と小領域

および分割した道路・河道要素を統合し, 高度な地物 データ GIS として構築する.

\section{3. 実流域への適用}

図-4 は本研究で高度な地物データ GIS の構築対象領 域とした神田川上流域の概要を示したものである. 神 田川は東京都三鷹市井の頭恩賜公園内にある井の頭池 にその源を発し，杉並区南部を東に流れ，中野区の区 境付近で善福寺池を水源とする善福寺川と合流し, 新 宿区に流入する一級河川である。 また本流域では, 著 者らが $1 / 2500$ 地形図や航空写真から手作業により高度 な地物データ GIS（以下これを「M-GIS」と呼ぶ）の 構築を行っている ${ }^{6,10), 21)}$. 本論文では, 図-4に示す井 の頭池から善福寺川合流点までの上流域約 $11.5 \mathrm{~km}^{2}$, 流 路延長 $9 \mathrm{~km}$ を対象流域に設定し, 15 葉の地形図データ を用いて高度な地物データ GIS の構築を行った．基礎 的地物データ GIS から高度な地物データ GIS の自動構 築を行う際に要した時間は, CPUに Intel（R）XEON （R）CPU 5520（2.27GHz）を用いた PCで概ね 3 日程 度であり, 手作業による構築に6r月程度要したことか ら大幅な構築時間の短縮に成功したといえる.

図-5 は神田川上流域を対象に, 本研究で開発した手 法により高度な地物データ GIS（以下これを「A-GIS」 と呼ぶ）の構築を行った結果, およびM-GIS を示した ものである. この図よりたとえば井の頭池周辺の緑地 の位置など，A-GIS と M-GIS 間で大まかに一致してい ることが見て取れる，以下では A-GIS と M-GIS につい

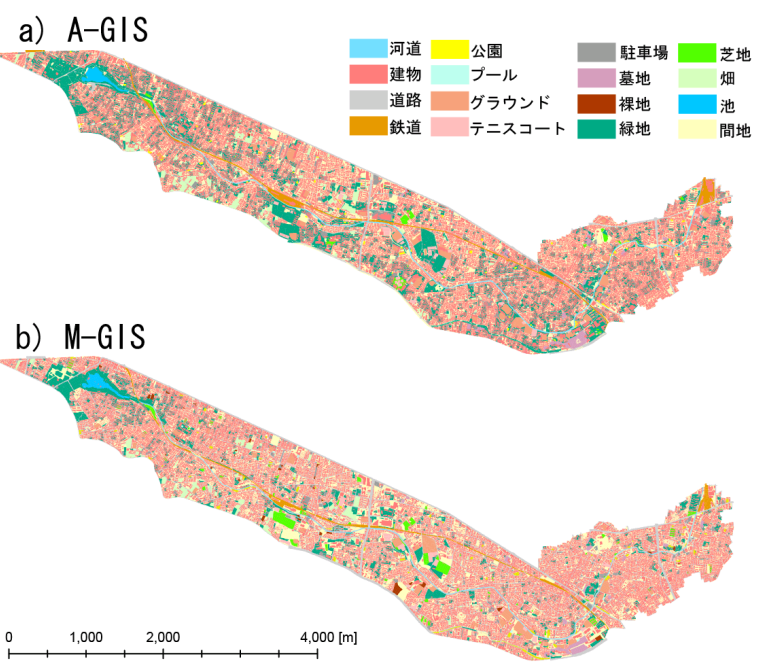

図-5 神田川上流域の高度な地物データ GIS の比較 
表-2 A-GIS ・ M-GIS の土地利用面積および面積率

\begin{tabular}{|c|c|c|c|c|}
\hline & \multicolumn{2}{|c|}{ A-GIS } & \multicolumn{2}{|c|}{ M-GIS } \\
\hline & 面積 [m²] & 面積率 [\%] & 面積 [m²] & 面積率 [\%] \\
\hline 河道 & 99,759 & 0.9 & 99,704 & 0.9 \\
\hline 建物 & $3,402,053$ & 29.6 & $3,382,236$ & 29.4 \\
\hline 道路 & $1,726,076$ & 15.0 & $1,785,662$ & 15.5 \\
\hline 鉄道 & 177,125 & 1.5 & 149,388 & 1.3 \\
\hline 公園 & 50,791 & 0.4 & 90,538 & 0.8 \\
\hline プール & 5,412 & 0.1 & 11,750 & 0.1 \\
\hline グラウンド & 258,868 & 2.3 & 248,945 & 2.2 \\
\hline テニスコート & 115,947 & 1.0 & 84,997 & 0.7 \\
\hline 駐車場 & 321,241 & 2.8 & 647,085 & 5.6 \\
\hline 墓地 & 86,163 & 0.8 & 70,392 & 0.6 \\
\hline 裸地 & 1,796 & 0.0 & 52,714 & 0.5 \\
\hline 緑地 & $2,006,551$ & 17.4 & $1,041,020$ & 9.1 \\
\hline 芝地 & 52,454 & 0.5 & 171,526 & 1.5 \\
\hline 畑 & 263,541 & 2.3 & 188,587 & 1.6 \\
\hline 池 & 51,421 & 0.5 & 50,402 & 0.4 \\
\hline 間地 & $2,885,047$ & 25.1 & $3,429,321$ & 29.8 \\
\hline 浸透域 & $4,278,634$ & 37.2 & $3,663,379$ & 31.8 \\
\hline 合計 & $11,504,244$ & - & $11,504,265$ & - \\
\hline
\end{tabular}

て各土地利用種別の合計面積から計算された面積率を 比較するとともに, 神田川上流域内の小領域 $500 \mathrm{~m} \times$ 500m について A-GIS, M-GIS および航空写真を比較 することにより本手法の妥当性を検証する.

\section{(1) 土地利用種別ごとの面積率を用いた考察}

表-2 は A-GIS および M-GIS の土地利用種別ごとの 面積および面積率を示したものである.ここで, A-GIS と M-GIS 間で合計要素面積が若干異なるのは, A-GIS の自動構築に伴う座標值の桁落ちによるものである.

本節では, 流域の浸透特性を把握するうえで重要な パラメータである, 各土地利用種別が流域全体に占め る面積率を用い, 基礎的地物データ GIS から直接構築 した河道, 建物, 道路, 池およびM-GIS と A-GIS の面 積率の差が $1 \%$ よりきい間地, 緑地, 駐車場に着目し て考察を行う.

まず河道, 建物, 道路, 池の面積率の差が他の土地 利用種別と比較し小さいことがわかる.これはこれら 要素がほぼ地形図データにより明示された境界線デー タのみから構築されているためと考えられる.

次いで間地については, A-GIS は25\%, M-GIS は30\% でA-GIS の面積率が 5\%程度小さい。ここで間地とは, 情報がなく属性が不明な地物のことであり, 主として 個々の宅地内の家屋以外の部分で占められる. よって この結果は自動化によってより多くの土地利用情報が 対象領域に与えられていることを示している.

また緑地は A-GIS が 8\%程度大きく, 最も大きな差 を生じている要素である. 浸透域である緑地の面積差 が流域全体の浸透特性に及ぼす影響を調べるため, 公 園, グラウンド, テニスコート, 墓地, 裸地, 緑地, 芝 地，畑および間地の $50 \%$ を浸透域とし，流域の浸透特 性の指標である浸透面積および面積率をそれぞれ計算 した。 その結果, A-GIS の浸透域が面積率で 5\%程度大 きいことがわかった。これについては次の小領域にお
ける検証でより詳しい解析と考察を行うものとする.

さらに駐車場では A-GIS の面積率が $2.8 \%$ 小さい。 こ れは駐車場要素を構築する際, A-GIS では駐車場の地 図記号のみを用いるのに対し，M-GIS では駐車場と街 区内の舗装地を加えた領域を駐車場としたためと考え られる。このように自動構築アルゴリズムで考慮され なかった M-GIS 作成時の考え方について取り入れるこ とにより, 自動構築の精度向上が期待できる。これに ついては今後の課題としたい.

\section{(2) 小領域における検証}

図-6 は小領域における A-GIS, M-GIS および航空写 真を示す．まず，表-2において A-GIS の要素面積が MGIS と比較して小さかった公園に着目する. 領域 A を 見ると, A-GIS での公園範囲が M-GIS のそれよりも狭 いことがわかる. 同領域を航空写真により精査すると, 公園外周部に樹木が植えられていることが読み取れる. このように A-GIS では公園などの樹木の部分を緑地と 設定し，より細かく地物を設定する特性がみられ，こ れが A-GIS において緑地の面積が大きくなる理由であ ると考えられる.

また，A-GIS の要素面積が小さかったプールに着目す る.たとえば領域 B に注目すると, A-GIS ではプール を水面とし，プールサイドについては間地と設定してい るのに対し，M-GIS では水面およびプールサイドを含 む領域にプールの属性を与えている.このため, A-GIS のプール面積は小さくなっていると考えられる.

次いで, 表-2では両者の面積の差が比較的小さいグ ラウンドと A-GIS の面積が過大となったテニスコート に着目する. 領域 C のグラウンドは, A-GIS と M-GIS で形状が大きく異なっている. また同領域の航空写真を 見ると, M-GIS のグラウンドの境界と実際のグラウン ドの境界は一致していることがわかる。ここで A-GIS に用いた地形図データを確認すると, 同領域にグラウン ドとして柵があるものの, ごく一部のみしか示されてい ないため境界として用いられていないことがわかった。

また領域 D のテニスコートに注目すると, 航空写真 から判断して A-GIS ではテニスコート形状をうまく再 現できていないことがわかる。この要素は地形図デー タによって境界線が明記されておらず，ティーセン分 割によって要素の形状が決定されている。これがグラ ウンドや他の街区内土地利用種別について, 形状が実 際と異なる一つの要因であると考えられる.

\section{4. むすび}

本研究では, 洪水流出解析に用いる土地利用データ として, 1/2500 地形図標準データファイルに着目し, 本 データから都市の複雑な土地利用形態を表現すること ができる高度な地物データ GIS の構築を自動化する手 法について開発を行うとともに, 本手法を神田川上流 域に適用してその妥当性について評価・検討を行った. 

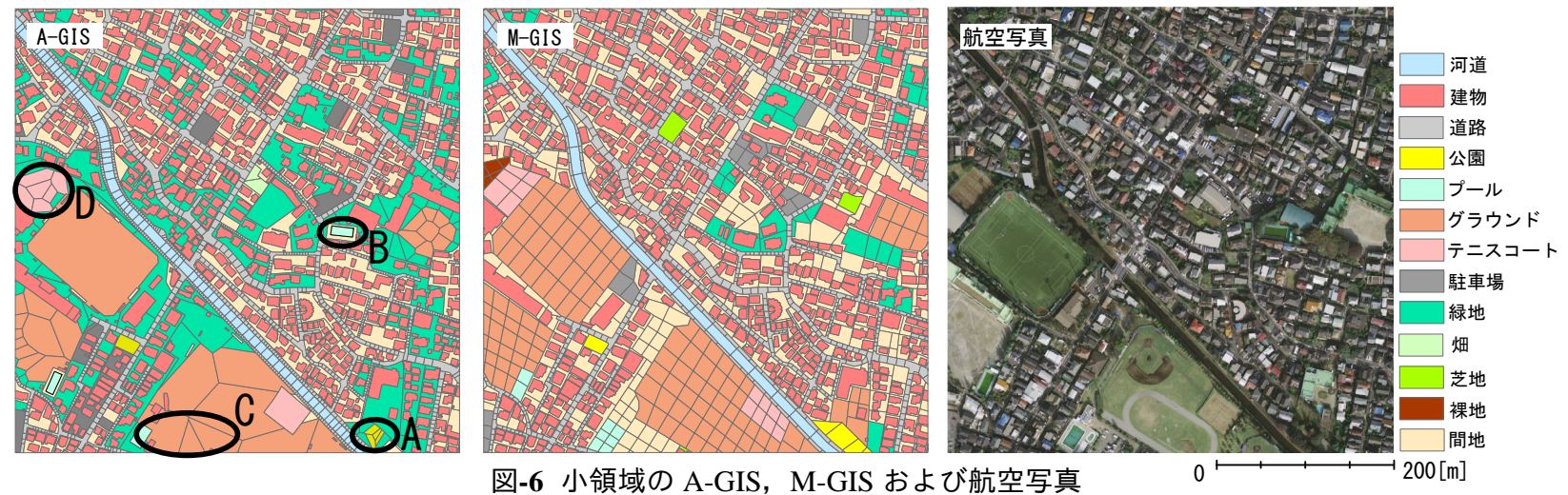

図-6 小領域の A-GIS，M-GIS および航空写真

この中で地図記号を入力データとし，ティーセン分割 の概念を用いた領域の分割手法を新たに開発し，地物 要素の土地利用情報を取得する手法として用いた。こ の結果, 地形図データが取得できる任意の流域で高度な 地物データ GIS を短時間で構築することが可能となっ た。また神田川上流域を対象とし，本手法を用い高度な 地物データ GIS の自動構築を行い，アルゴリズムの検 証を行った。 その結果, 自動化により特に対象流域の植 生について手作業と比較しより詳しく設定できること を確認した。一方で手作業と自動構築アルゴリズムで の考え方の違いが構築結果に影響することがわかった。 また地形図により境界が明示されていない場合，自動 構築した地物の形状が実際と異なることを確認した。

今後はこれら問題を踏まえ，より実際を再現できる 分割手法について考案・実装する予定である。 また水 循環モデルへの適用に向けて, 各要素を適切な大きさ と形に分割する手法について開発する予定である.

謝辞 : 本研究を遂行するにあたって, 東京都アジア高 度研究「アジア都市圈における水問題解決のための適 応策に関する研究」(代表 : 河村明) の補助を受けまし た。ここに記して深謝申し上げます。

\section{参考文献}

1) 忌部正博, 屋井裕幸, 高祖成一: 都市域の健全な水循環 系構築のための雨水浸透施設の効果と評価について, 日 本水文学会誌，第 38 巻，第 2 号，pp.3-54,2008.

2) 賈仰文, 倪广恒, 河原能久, 未次忠司: 都市河川流域の 水循環解析と雨水浸透施設の効果の評価, 水工学論文集, 第 44 巻, pp.151-156,2000.

3) 天口英雄, 安藤義久: SMPT モデルを用いた分布型水 循環モデルの改良について, 水工学論文集, 第 46 巻, pp.265-270,2002.

4) 中村茂 : グリッド型水循環系解析モデルの開発〜海老川 流域を対象として〜, 水工学論文集, 第 45 巻, pp.103108,2001

5) 古賀達也, 河村明, 天口英雄: 神田川上流域における高

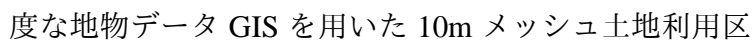
分の浸透面積率に関する研究, 土木学会論文集 B1（水 工学), Vol.68,No.4, pp.I_505-I_510,2012.

6) 天口英雄, 河村明, 高崎忠勝: 地物データ GIS を用いた 新たな地物指向型都市洪水流出解析モデルの提案, 土木 学会論文集 B, Vol.63,No3,pp.206-223,2007.

7) 天口英雄, 河村明, 高崎忠勝, 中川直子: 個別の地物情報を
考慮した密集市街地における Tokyo Storm Runoff Model の提案, 水工学論文集, 第 55 巻, pp.S_517-S_522,2011.

8) Amaguchi, H., Kawamura, A., Olsson, J. and Takasaki, T. : Development and testing of a distributed urban storm runoff event model with a vector-based catchment delineation. Journal of Hydrology, No.420-421, pp.205-215, 2012.

9) 荒木千博, 河村明, 天口英雄, 高崎忠勝, 土屋大: 個別 の浸透施設の効果を組み込んだ地下水涵養モデルの構築 水工学論文集, 第 54 巻, pp.559-564,2010.

10) 荒木千博, 河村明, 天口英雄, 高崎忠勝: 地物データ GIS を用いた都市流域地下水涵養モデルの構築および 実流域シミュレーション, 土木学会論文集 B (水工学), Vol.68,No.2,pp.109-124,2012.

11) Sample, D.J., Heaney J.P.,Write, L.T., Koustas, R., : Geographic information systems, decision support systems, and urban storm-water management. J. Water Resour. Plan. Manage. ASCE 127 (3), 155-161, 2001.

12) Rodriguez, F., Andrieu, H., Morena, F. : A distributed hydrological model for urbanized areas - model development and application to case studies. Journal of Hydrology, No.351, pp.268-287, 2008.

13) 田内裕人, 天口英雄, 河村明, 中川直子 : 1/2500 地形図 標準データファイルを用いた高度な地物データ GIS 自動 構築手法の第一歩, 第 39 回土木学会関東支部技術研究 発表会,2012.

14）津留宏介: 小特集 ALOS/PRISMによる地図作製に関する 検証, 写真測量とリモートセンシング, Vol.48,No.2,pp5881,2009 .

15) 村山健二, 正司哲郎, 平林哲, 岡田至弘: 分割 K-平均法に よる領域分割結果を用いた航空写真からの道路抽出, 写 真測量とリモートセンシング, Vol.42,No.2,pp.4-11,2003.

16) 国土交通省 国土地理院: 数值地図 2500,http://www.gsi.go .jp/geoinfo/dmap/dm2500sdf/index.html,2011.10.15

17) 東京都都市整備局 : 東京都縮尺 $1 / 2500$ 地形困 標準デー タファイル,http://www.toshiseibi.metro.tokyo.jp/kiban /map_user/index.html,2011.9.13

18）国土地理院 : 公共測量ビューア・コンバータ,http:// psgsv.gsi.go.jp/koukyou/public/sien/pindex.html,2011.9.8

19) Esri Japan : ArcGIS http://www.esrij.com/products/arcgis/, 2011.9.12

20）国土交通省道路局：道路構造令・標識令 http://www.mlit.go.jp/road/sign/hyoshikitop.html,2012.8.9

21) 村松健司, 天口英雄, 河村明 : 神田川上流域を対象とし た都市洪水流出モデルに対する地物データ GIS の構築, 第 35 回土木学会関東支部技術研究発表会, 2008 .

(2012.9.30 受付) 